\title{
Research on the Impact of Returnee Executives' Strategic CSR Orientation on Corporate Value
}

\author{
Zhiyuan Liao ${ }^{1}$, Zhiqing Huang ${ }^{1}$, Canming Fang ${ }^{1}$ \\ ${ }^{1}$ Finance Department of International Business School, Jinan University, Guangdong, China 519070 \\ Correspondence: Zhiqing Huang, Finance Department of International Business School, Jinan University, Qianshan \\ Road 206\#, Zhuhai City, Guangdong Province, Post No.519070, China.
}

Received: March 17, 2020

doi:10.11114/aef.v7i3.4770
Accepted: April 23, $2020 \quad$ Available online: April 28, 2020

URL: https://doi.org/10.11114/aef.v7i3.4770

\begin{abstract}
An increasing number of studies have focused on the impact of the increase in the proportion of overseas returnees in enterprise management. How do executives with an overseas background affect corporate value? Based on Upper Echelons Theory, this paper studies the influence of overseas returnees on enterprise value from the perspective of strategic corporate social responsibility. Based on the sample composed of companies listed in Shanghai and Shenzhen stock exchange, the research shows that executives from overseas through strengthening strategic corporate social responsibility, make the enterprise social responsibility incorporated into the development of business strategy, finally promoting the ascension of the enterprise value. Namely, the strategic corporate social responsibility orientation plays an intermediary role between executives from overseas and enterprise value. This study further correlates the characteristics of overseas returnees with the strategic decisions of enterprises, deepens the understanding of the realization mechanism of overseas executives' promotion of corporate value, enriches the research results of factors influencing corporate social responsibility, to improve the active construction of local enterprises' social responsibility by changing the structure of the executive.
\end{abstract}

Keywords: returnee executives, strategic corporate social responsibility, enterprise value, upper echelons theory, mediating effect

\section{Introduction}

In the background of China's "export-oriented economy" and economic globalization, more and more managers with overseas study backgrounds are entering the senior management team of enterprises. They are playing an increasingly important role in all aspects of business management. Many studies have concentrated on this changing trend and carried out discussions from the aspects of technological innovation, strategic choice, risk management, etc., indicating that senior executives with the overseas background can help improve the economic performance, innovation performance, and risk-bearing capacity of enterprises. These researches are carried out from a managerial perspective more than the strategic decision perspective.

The executive management structure is an influential factor in CSR (Corporate Social Responsibility) performance. Studies have shown that returnee executives have a positive effect on the construction of corporate social responsibility (Xu et al., 2018). A study also shows that the proportion of executives with the overseas background is positively correlated with corporate social responsibility decision-making (Wen and Song, 2017). These studies have expanded people's understanding of the influence of overseas returnees on corporate social responsibility. However, these studies fail to distinguish between the influence paths of returnee executives and ordinary executives in the CSR construction.

Based on the above analysis, this paper argues that, due to their internationalized education or professional background, overseas executives have a more advanced strategy making pattern and a stronger sense of responsibility, tend to consider more about social responsibility in decision-making. Therefore, from the perspective of strategic corporate social responsibility, this paper hopes to analyze the impact of the strategic corporate social responsibility orientation of returnee executives on enterprise value based on Upper Echelons Theory.

This paper will expand on the implementation mechanism of how executives with overseas background influence the enterprise value via both the management and the whole strategy-making process. Besides, this paper furthers the research on the relationship between returnee executives and the economic performance of the enterprise and enriches 
quantitative research on the factors influencing corporate social responsibility, thus providing insights into domestic enterprise social responsibility construction.

\section{Literature Review}

\subsection{Research on the Influence of Returnee Executives on Enterprises}

With the gradual expansion of the number of overseas returnees, their influence on various aspects of enterprises has attracted the attention of scholars, and relevant studies have been gradually enriched. Many pieces of research focus on the contribution of returnees to the innovation and development of enterprises in their home countries, such as the positive role of returnees in international technology transfer, which improves the enterprises' innovation capacity. Returnees also play a significant role in other aspects of the enterprises.

The study of $\mathrm{Xu}$ and Sun (2008) indicated that returnee executives play an important role in promoting the export competitiveness of the enterprise. Wen and Song (2017) found that the more corporate executives with overseas backgrounds, the higher risk the enterprise can take. He and Zhang (2018) studied the relationship between returnee executives and earnings management. It can be seen that returnees have influenced enterprises a lot after they enter the management section. On the whole, they exert a very important and positive influence on the development of enterprises.

The advanced management skills that returnees have acquired in developed countries will help fill the gap between home and developed countries. In the development of corporate social responsibility, China is relatively backward compared with developed countries. In recent years, some studies have begun to focus on the influence of overseas returnee executives on CSR construction. For example, the executive's overseas study and work background have a significantly positive impact on the fulfillment of corporate social responsibility (Wen and Song, 2007). Xu and Zhu (2008) emphasized that overseas returnee executives improve CSR performance through the mechanism of cultural convergence. The above research results showed that the overseas returnee executives have an impact on the enterprise operation through the construction of CSR, but the internal impact mechanism has not been deeply discussed.

\subsection{Research on the Impact of Strategic Corporate Social Responsibility on Corporate Value}

The influence of corporate social responsibility on corporate value has been widely discussed in academic fields. It can be divided into the traditional view and strategic view of corporate social responsibility. The traditional view of corporate social responsibility argues that the implementation of corporate social responsibility is relatively independent of the management decision system of the enterprise, that is to say, they are not integrated into the enterprise's operation system. The impact of CSR on the enterprise's operation decision is very limited (Lu, 2001), and there is even a contradiction between social responsibility and the maximization of corporate interests (Chen, 2010).

Contrary to the traditional view of CSR, the strategic view of CSR emphasizes the interdependent shared value between enterprises and society. Through social responsibility, enterprises reconstruct the relationship between enterprises and society and finally realize the shared value. In this view, social responsibility can provide support for the core business of enterprises, help improve operating efficiency and bring both social and economic benefits to enterprises.

Through the literature review, this paper compares the two concepts between traditional CSR and SCSR, which can be summarized in the following table.

Table 1. Comparison of a traditional and strategic view of social responsibility

\begin{tabular}{l|c|c}
\hline & Traditional CSR & SCSR \\
\hline Starting point & Enterprises & Enterprises and society \\
\hline Emphasis point & Short-term interests & $\begin{array}{c}\text { Long-term and sustainable } \\
\text { benefits }\end{array}$ \\
\hline Incentives & Response to social pressure & Strategic and voluntary \\
\hline Goal & The welfare of society & Maximize the shared value \\
\hline $\begin{array}{l}\text { Relationship between enterprises } \\
\text { and society }\end{array}$ & Zero-sum game & Positive-sum game \\
\hline
\end{tabular}

Note: Derived from the corresponding literature.

SCSR emphasizes the close relation between corporate social responsibility and corporate strategic decisions, requiring enterprises to deal with CSR actively. The existing researches discuss the concept definition, connotation characteristics, 
dimension measurement, and decision-making mechanism of strategic social responsibility. Some researchers also focus on the positive influence of SCSR on the enterprise, such as to help enterprises establish and maintain the brand assets and increase brand loyalty of consumers (Xia, 2010), to enable transnational enterprises to overcome the disadvantage as outsiders to establish a good relationship with the stakeholders and achieve a win-win situation (Ren \& Guo, 2017).

The SCSR has gradually become an important theoretical viewpoint of corporate social responsibility, which needs subsequent research from multiple perspectives to gain an in-depth understanding of its impact on the enterprise.

\section{Method}

\subsection{Theoretical Analysis and Research Assumptions}

\section{1) Returnee Executives and SCSR Guide}

Based on the perspective of upper echelon theory, in an uncertain and complex market, corporate decision-making behavior is an overall reflection of the values of executives. The different experiences of corporate executives will have different effects on corporate decisions, and the demographic characteristics of senior executives (such as age, gender, educational background, overseas background, performance experience, etc.) are effective antecedents of their cognitive patterns and values (Li, 2018). Executives' overseas experiences have an impact on their values and perception of the outside world, which in turn affect corporate decisions. Especially, in the field of corporate social responsibility, corporate social responsibility awareness is the antecedent variable in the corporate social responsibility management model (Liu, 2013). Therefore, returnee executives' corporate social responsibility cognition and values will be affected by their overseas background, which in turn will affect the social responsibility decisions of their companies.

On the one hand, compared with local executives, overseas returnees have a deeper understanding of CSR. The concept and practice of corporate social responsibility are influenced by cultural characteristics and systems (Liu, 2013). Compared with western developed countries, the construction of the CSR system in China is relatively backward, the strategic positioning obscure, and practical application unguided (Lu, 2017). The national education of corporate social responsibility in China is obviously insufficient, and there is a lack of external conditions for the cultivation of entrepreneurs' awareness of corporate social responsibility (Yi,2012). During their stay in developed countries, overseas returnees can directly contact with cutting-edge corporate social responsibility practices, and it is easier for them to identify with the concept of corporate social responsibility (Jia, 2006).

On the other hand, overseas returnees are more likely to take CSR into strategic consideration of the enterprise's prospect and management. First of all, in the case of separation of ownership and management of the enterprise, senior management team members, as important decision-makers in formulating and implementing corporate social responsibility strategies $(\mathrm{Li}, 2017)$, hold the right of management of the enterprise. Secondly, the returnees' overseas experience endows them with the potential to promote the healthy development of enterprises and gives them a more advanced strategy making pattern. As high-end talents with overseas experience, overseas returnee executives can well fill the gap in the international experience in the development of CSR in China in the present stage (Li, 2010). Overseas returnee executives are more likely to win the trust of their partners, and they are expected to use the advanced experience gained from overseas to improve corporate decision-making (Fei, 2010).

This article makes the following assumptions:

H1: With other conditions unchanged, returnee executives improve the strategic corporate social responsibility orientation of their companies.

\section{2) Returnee executives'impact on the enterprise value}

According to the upper echelon theory, when senior executives with overseas study or work experience return to their home country to work for a company, such experience will affect the business results of the company by influencing the executives' cognitive patterns and behavioral choices when making operational or strategic decisions. (An, 2018).

On the one hand, the theory that human capital promotes economic growth holds that human capital can have a positive impact on the value of the company (Rosen S, 2008). Executives with overseas study backgrounds often receive high-quality overseas education and undergo more advanced and scientific academic training, forming broader thinking scope and mastering frontier professional knowledge (Zhang and $\mathrm{Wu}, 2016$ ). As a proxy for education level, education degree often reflects one's learning capability. Managers with profound knowledge are often regarded as able to receive new ideas and collect relevant information more effectively, thus improving their management level of the enterprise. Existing studies show that highly educated executive team members tend to have stronger information processing ability and can deal with complex problems in the context of uncertainty, which has a positive effect on corporate performance (Zhang and $\mathrm{Li}, 2007$ ). Also, overseas study experience helps executives in the risk decision-making process, which is conducive to the firm's stable survival and long-term development (Zhouwei, 2014).

On the other hand, the transnational experience can be gained by executives through overseas practice. Transnational 
work experience can be continuously applied to the strategic decision-making process to help enterprises grow in the international market. Yu Hui and Shen Shumeng (2010) believe that transnational experience will bring enterprises international market experience, skills, and management philosophy, and enable the senior management team to make a better assessment of the market environment. In addition, it is found that enterprises with overseas returnees have better investment results, with returnee managers reducing the excessive investment behavior of enterprises (Wang and Gao, 2018)

$\mathrm{H} 2$ : With other conditions unchanged, returnee executives play a positive role in promoting enterprise value.

\section{3) Strategic CSR orientation's intermediary role}

SCSR orientation affects the promotion of corporate value. For different stakeholders, corresponding CSR performance has a certain impact on corporate value. However, different from traditional social responsibility practices, SCSR-oriented executives can create mutual benefits for both the enterprise and society, contributing to the enhancement of corporate value by strengthening the corporate strategy and improving the enterprise competitive advantages (Song, 2012).

Maximizing shared value has become an important criterion for evaluating the sustainable competitive advantages of SCSR. SCSR decision-making is crucial to finding the intersection of the interests between enterprises and society, so it is important to identify what social issues match the ability of enterprises. By using value chain analysis, senior executives emphasize the impact of business activities on society from the inside out by identifying and planning subdivision projects relevant to social responsibility, so as to integrate social responsibility into corporate strategy and optimize the coordination of internal activities. Senior executives can also use the diamond model to strategically fulfill their social responsibilities from the outside to the inside, improving the external competitive environment and promoting sustainable competitiveness simultaneously (Shao \& Meng, 2015). With the orientation to SCSR, returnee executives will use their personal understanding of corporate social responsibility and practical experience to strategically identify CSR problem in the current development of the enterprise, through the value chain analysis as well as the improvement of the external competitive environment of the enterprise to realize the value of enterprises.

This article makes the following assumptions:

H3: With other conditions remain unchanged, strategic corporate social responsibility orientation plays an intermediary role between executives and enterprise value.

\subsection{Research Samples and Data Sources}

This paper selects the CSR reports disclosed by Shanghai and Shenzhen stock exchange in 2009-2016 and reviews the company reports that are included in the "Ringling Global Responsibility Rating ( RKS ) ". After removing the observations which miss the main variables and excluding foreign companies, finance companies, and ST companies (Special Treatment), we will get 4397 annual company observations. On this basis, this paper sorts out the information about overseas education and work experience of executives of listed companies by manually reviewing the company's annual report and CSMAR database. This paper selects EXCEL 2010 for processing relevant data and uses SPSS17.0 as well as EVIEWS 6.0 for statistical analysis. In order to reduce the influence of the outliers, this paper performs a Winsorize process of $1 \%$ on all continuous variables.

\subsection{Equation Setting}

To empirically examine the impact of returnee executives on corporate value through strategic corporate social responsibility-oriented intermediary channels, this paper learns from the approach of Wen et al. (2004) and constructs the following recursive model to test the effect of returnee executives on corporate value and the mediation effect of SCSR orientation.

We construct the following empirical model

$$
\text { Tobin } Q_{i t}=a_{0}+a_{1} \text { FOR }_{\text {it }}+a_{2} \text { SIZE }_{i t}+a_{3} \text { ROA }_{i t}+a_{4} \text { LEV }_{i t}+a_{5} \text { GROW }_{i t}+a_{6} \text { STATE }_{i t}+\varepsilon_{i t}
$$

If the key coefficient $\alpha 1$ of Equation 1 is significantly positive, it indicates that returnee executives can significantly promote the value of the enterprise, and $\mathrm{H} 2$ is supported by empirical evidence.

In order to test the existence of the impact path in $\mathrm{H} 3$, according to the mediation effect test idea described by Wen, this paper first establishes a model of strategic corporate responsibility and returnee executives, that is

$$
S C S R_{i t}=\beta_{0}+\beta_{1}\left(\frac{\frac{P_{-} F O R_{i t}}{\text { PROP_FOR }_{i t}}}{J P_{-} F O R_{i t}}\right)+\beta_{2} S I Z E_{i t}+\beta_{3} R O A_{i t}+\beta_{4} L E V_{i t}
$$




$$
+\beta_{6} \mathrm{GROW}_{\mathrm{it}}+\beta_{7} \mathrm{STATE}_{\mathrm{it}}+\beta_{8} \mathrm{AGE}_{\mathrm{it}}+\beta_{9} \mathrm{LEAD}_{\mathrm{it}}+\varepsilon_{\mathrm{it}}
$$

If $\beta 1$ of Equation 2 is significantly positive, it indicates that returnee executives can significantly promote the strategic corporate social responsibility orientation, and $\mathrm{H} 1$ is supported by empirical evidence.

$$
\begin{aligned}
& \text { TobinQ } Q_{\text {it }}=\gamma_{0}+\gamma_{1} \mathrm{SCSR}_{\text {it }}+\gamma_{2} \mathrm{SIZE}_{\text {it }}+\gamma_{3} \mathrm{ROA}_{\text {it }}+\gamma_{4} \mathrm{LEV}_{\text {it }}+\gamma_{5} \mathrm{GROW}_{\mathrm{it}}+\gamma_{6} \mathrm{STATE}_{\mathrm{it}}+\varepsilon_{\mathrm{it}}
\end{aligned}
$$

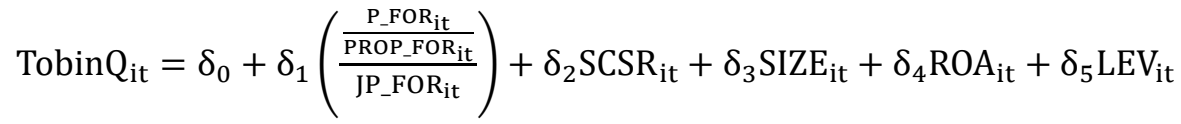

$$
\begin{aligned}
& +\delta_{6} \mathrm{GROW}_{\mathrm{it}}+\delta_{7} \mathrm{STATE}_{\mathrm{it}}+\delta_{8} \mathrm{AGE}_{\mathrm{it}}+\delta_{9} \mathrm{LEAD}_{\mathrm{it}}+\varepsilon_{\mathrm{it}}
\end{aligned}
$$

If $\alpha_{1}, \beta_{1}, \gamma_{1}$ and $\delta_{1}, \delta_{2}$ of formula ( 1 ) - ( 4 ) are significant, it indicates that the executive returnee executives impact the enterprise value at least in part by " strategically oriented CSR ", thus H3 is supported by empirical evidence.

\subsection{Variable Definitions}

1) The interpreted variable is TobinQ. This article measures the value of the enterprises based on Tobin Q's approach of corporate value assessment.

2) The explanatory variable is FOR, a measure of the human capital advantage of returnee executives, especially the advantage of economics, management, and strategic ideas. But this advantage is difficult to measure. According to the upper echelons theory, the background characteristics of the executive team are closely related to the cognitive ability and values of the manager. The cognitive ability and values of executives will affect their strategic decisions, so strategic CSR oriented decisions are influenced by the cognitive ability and values of executives. The values and cognition of the senior management team are based on the background characteristics of senior management. Therefore, background characteristics of senior executives such as their education level, work experience, and professional background will inevitably affect CSR. Specifically, it is measured from three aspects: P_FOR indicates the proportion of returnee executives in the total number of corporate executive teams; PROP_FOR indicates the proportion of returnee executives with economic and management backgrounds in the number of corporate executives, JP_FOR represents the proportion of returnee executives with overseas work experience in the number of corporate executives.

3) The intermediary variable SCSR is regarded as a measure of corporate strategic social responsibility orientation. Rather than Runling Global 's corporate social responsibility rating level or rating score, this article chooses the sum of the integrity (M) of CSR strategy and content (C) of CSR action performance in Runling Global's CSR report. In order to measure whether an enterprise has a strategic CSR orientation, it is necessary to first see whether the enterprise has incorporated CSR into its strategic system and formed a CSR strategy, secondly pay attention to whether the enterprise can fulfill its social responsibility strategy according to it.

4) The control variable refers to the practice of Du et al. (2011). In this paper, the company size (SIZE), asset-liability ratio (LEV), corporate growth (GROW), return on assets (ROA), and property right nature (STATE) are added to formula (1). Referring to the practice of Li Jing et al. (2018), the asset-liability ratio (LEV), return on assets (ROA), corporate growth (GROW), and company size ( SIZE), company age (AGE), the nature of the company's property rights (STATE), the company leader dummy variable (LEAD), etc. are added to equation(2) as control variables.

\subsection{Pearson Correlation Analysis of Various Variables}

Table 2 reports the results of correlation analysis among the main variables. It can be found that the correlation coefficients between the variables SCSR and P_FOR, PROP_FOR, and JP_FOR are 0.136, 0.137, and 0.117, and the significance levels are all $1 \%$. This indicates that there is a significant positive correlation between strategic CSR orientation and whether to employ overseas returnee executives, the proportion of overseas returnee executives with overseas economic and management background in the executive team, and the proportion of overseas returnee executives with overseas work and work experience in the executive team. At the same time, the correlation coefficient between the variables TobinQ and SCSR is 0.114 , and the significance level is $1 \%$. This means that corporate value is significantly positively related to strategic corporate social responsibility orientation. We also find that the variable TobinQ is significantly positively related to GROW and ROA, that is, the value of the company is seriously affected by the growth of the company itself and the return on total assets. 
Table 2. Correlation analysis of main variables

\begin{tabular}{|c|c|c|c|c|c|c|c|c|c|c|c|c|}
\hline & TobinQ & P_FOR & $\begin{array}{c}\text { PROP_F } \\
\text { OR }\end{array}$ & JP_FOR & SCSR & SIZE & ROA & LEV & GROW & AGE & $\begin{array}{l}\text { STAT } \\
\text { E }\end{array}$ & $\begin{array}{c}\text { LEA } \\
\text { D }\end{array}$ \\
\hline TobinQ & 1 & & & & & & & & & & & \\
\hline P_FOR & $\begin{array}{c}-0.0080 \\
0\end{array}$ & 1 & & & & & & & & & & \\
\hline $\begin{array}{c}\text { PROP_F } \\
\text { OR }\end{array}$ & $\begin{array}{c}-0.0080 \\
0 \\
\end{array}$ & $\begin{array}{c}0.997 * * \\
* \\
\end{array}$ & 1 & & & & & & & & & \\
\hline JP_FOR & 0.0100 & $\begin{array}{c}0.797 * * \\
*\end{array}$ & $0.795 * * *$ & 1 & & & & & & & & \\
\hline SCSR & $\begin{array}{c}0.114 * * \\
*\end{array}$ & $\begin{array}{c}0.136 * * \\
*\end{array}$ & $0.137 * * *$ & $\begin{array}{c}0.117 * * \\
*\end{array}$ & 1 & & & & & & & \\
\hline SIZE & $\begin{array}{c}-0.485^{*} \\
* *\end{array}$ & $\begin{array}{c}0.127 * * \\
*\end{array}$ & $0.127 * * *$ & $\begin{array}{c}0.087 * * \\
*\end{array}$ & $\begin{array}{c}0.435^{* * *} \\
*\end{array}$ & 1 & & & & & & \\
\hline ROA & $\begin{array}{c}0.318^{* *} \\
*\end{array}$ & $\begin{array}{c}-0.0070 \\
0\end{array}$ & -0.00500 & -0.0220 & $\begin{array}{c}-0.0040 \\
0\end{array}$ & $\begin{array}{c}-0.086^{*} \\
* *\end{array}$ & 1 & & & & & \\
\hline LEV & $\begin{array}{c}-0.435^{*} \\
* *\end{array}$ & 0.00400 & 0.00100 & 0.0240 & $\begin{array}{c}0.094 * * \\
*\end{array}$ & $\begin{array}{c}0.515^{* *} \\
*\end{array}$ & $\begin{array}{c}-0.434 * \\
* *\end{array}$ & 1 & & & & \\
\hline GROW & $0.034 * *$ & 0.0150 & 0.0160 & 0.00400 & $\begin{array}{c}-0.046^{*} \\
* *\end{array}$ & 0.0120 & $\begin{array}{c}0.280^{* * *} \\
*\end{array}$ & $\begin{array}{c}0.033^{*} \\
*\end{array}$ & 1 & & & \\
\hline STATE & $\begin{array}{c}-0.159 * \\
* *\end{array}$ & $\begin{array}{c}-0.066^{*} \\
* *\end{array}$ & $-0.065^{* * *}$ & $\begin{array}{c}-0.068 * \\
* *\end{array}$ & $\begin{array}{c}0.099^{* *} \\
*\end{array}$ & $\begin{array}{c}0.303 * * \\
*\end{array}$ & $\begin{array}{c}-0.151^{*} \\
* *\end{array}$ & $\begin{array}{c}0.187 * \\
* *\end{array}$ & $\begin{array}{c}-0.101^{*} \\
* *\end{array}$ & 1 & & \\
\hline AGE & $\begin{array}{c}-0.0080 \\
0\end{array}$ & $\begin{array}{c}-0.061^{*} \\
* *\end{array}$ & $-0.060 * * *$ & -0.0210 & $\begin{array}{c}0.053^{* * *} \\
*\end{array}$ & $0.034 * *$ & $\begin{array}{c}-0.075^{*} \\
* *\end{array}$ & $\begin{array}{c}0.075^{*} \\
* *\end{array}$ & $\begin{array}{c}-0.052^{*} \\
* *\end{array}$ & $\begin{array}{c}-0.060 * \\
* *\end{array}$ & 1 & \\
\hline LEAD & 0.0230 & $\begin{array}{c}0.611 * * \\
*\end{array}$ & $0.611 * * *$ & $\begin{array}{c}0.493 * * \\
*\end{array}$ & $\begin{array}{c}0.049 * * \\
*\end{array}$ & 0.0140 & -0.0180 & -0.0230 & $\begin{array}{c}-0.0060 \\
0\end{array}$ & $\begin{array}{c}-0.080 * \\
* *\end{array}$ & $\begin{array}{c}-0.016 \\
0\end{array}$ & 1 \\
\hline
\end{tabular}

\section{Empirical Results and Analysis}

The empirical test sequence is: firstly, controlling corporate characteristics and other related variables, examine the impact of returnee executives on strategic corporate social responsibility orientation and corporate value; secondly, using the mediating effect test proposed by Wen Zhonglin (2004), uses a recursive model to test the existence of strategic corporate social responsibility-oriented intermediary channels between returnee executives and corporate value. Therefore, the test of each hypothesis is in the recursive model.

This paper uses the least squares regression model while using the robust standard error to handle heteroskedasticity, adding industry, and annual dummy variables as regressors. Tables 3, 4, and 5 show the results of each regression test.

Table 3. P_FOR Regression results

\begin{tabular}{lcccc}
\hline & $(1)$ & $(2)$ & $(3)$ & $(4)$ \\
VARIABLES & $\mathrm{m} 1$ & $\mathrm{~m} 2$ & $\mathrm{~m} 3$ & $\mathrm{~m} 4$ \\
\hline P_FOR & $0.379^{* *}$ & $6.886^{* * *}$ & & TobinQ \\
\hline & $(2.233)$ & $(3.559)$ & & $0.339^{* *}$ \\
SCSR & & & $0.00603 * * *$ & $0.00582^{* * * *}$ \\
& & & $(4.227)$ & $(4.087)$ \\
SIZE & $-0.340^{* * *}$ & $3.186 * * *$ & $-0.355^{* * *}$ & $-0.358^{* * *}$ \\
& $(-25.16)$ & $(25.12)$ & $(-24.98)$ & $(-24.74)$ \\
ROA & $5.846^{* * *}$ & 3.209 & $5.811^{* * *}$ & $5.828^{* * *}$ \\
& $(12.88)$ & $(1.217)$ & $(12.82)$ & $(12.84)$ \\
LEV & $-0.438 * * *$ & $-5.701 * * *$ & $-0.411^{* * *}$ & $-0.405 * * *$ \\
& $(-3.763)$ & $(-6.631)$ & $(-3.510)$ & $(-3.455)$ \\
GROW & -0.0607 & -0.0386 & -0.0583 & -0.0605 \\
& $(-1.077)$ & $(-0.0806)$ & $(-1.033)$ & $(-1.072)$ \\
STATE & $0.206 * * *$ & -0.267 & $0.203 * * *$ & $0.207 * * *$ \\
& $(6.371)$ & $(-0.970)$ & $(6.323)$ & $(6.422)$ \\
AGE & -0.00210 & -0.0304 & -0.00225 & -0.00192 \\
& $(-0.739)$ & $(-1.002)$ & $(-0.803)$ & $(-0.680)$ \\
LEAD & 0.00219 & -0.640 & 0.0836 & 0.00591 \\
& $(0.0295)$ & $(-0.983)$ & $(1.426)$ & $(0.0796)$ \\
Constant & $9.150 * * *$ & $-43.43 * * *$ & $9.327 * * *$ & $9.403 * * *$ \\
& $(31.85)$ & $(-16.04)$ & $(31.99)$ & $(31.68)$ \\
Observations & 4,397 & 4,397 & 4,397 & 4,397 \\
R-squared & 0.443 & 0.296 & 0.444 & 0.445 \\
\hline
\end{tabular}


Table 4. PROP_FOR Regression results

\begin{tabular}{|c|c|c|c|c|}
\hline & $\begin{array}{c}\text { (1) } \\
\mathrm{mm} 1\end{array}$ & $\begin{array}{c}(2) \\
\mathrm{mm} 2\end{array}$ & $\begin{array}{c}(3) \\
\mathrm{mm} 3\end{array}$ & $\begin{array}{c}(4) \\
\mathrm{mm} 4\end{array}$ \\
\hline VARIABLES & TobinQ & SCSR & TobinQ & TobinQ \\
\hline \multirow[t]{2}{*}{ PFOP_FOR } & $0.365 * *$ & $7.071 * * *$ & & $0.324 *$ \\
\hline & $(2.140)$ & (3.629) & & (1.898) \\
\hline \multirow[t]{2}{*}{ SCSR } & & & $0.00603 * * *$ & $0.00583 * * *$ \\
\hline & & & $(4.227)$ & (4.090) \\
\hline \multirow[t]{2}{*}{ SIZE } & $-0.340 * * *$ & $3.184 * * *$ & $-0.355 * * *$ & $-0.358 * * *$ \\
\hline & $(-25.16)$ & (25.11) & $(-24.98)$ & $(-24.74)$ \\
\hline \multirow[t]{2}{*}{ ROA } & $5.845 * * *$ & 3.199 & $5.811 * * *$ & $5.826 * * *$ \\
\hline & (12.88) & (1.213) & (12.82) & (12.83) \\
\hline \multirow[t]{2}{*}{ LEV } & $-0.438 * * *$ & $-5.689 * * *$ & $-0.411 * * *$ & $-0.405 * * *$ \\
\hline & $(-3.762)$ & $(-6.616)$ & $(-3.510)$ & $(-3.455)$ \\
\hline \multirow[t]{2}{*}{ GROW } & -0.0607 & -0.0407 & -0.0583 & -0.0604 \\
\hline & $(-1.076)$ & $(-0.0851)$ & $(-1.033)$ & $(-1.071)$ \\
\hline \multirow[t]{2}{*}{ STATE } & $0.205^{* * *}$ & -0.268 & $0.203 * * *$ & $0.207 * * *$ \\
\hline & $(6.362)$ & $(-0.971)$ & $(6.323)$ & $(6.413)$ \\
\hline \multirow[t]{2}{*}{ AGE } & -0.00213 & -0.0306 & -0.00225 & -0.00195 \\
\hline & $(-0.749)$ & $(-1.006)$ & $(-0.803)$ & $(-0.690)$ \\
\hline \multirow[t]{2}{*}{ LEAD } & 0.00573 & -0.675 & 0.0836 & 0.00967 \\
\hline & $(0.0768)$ & $(-1.039)$ & (1.426) & $(0.130)$ \\
\hline \multirow[t]{2}{*}{ Constant } & $9.146^{* * *}$ & $-43.39 * * *$ & $9.327 * * *$ & $9.399 * * *$ \\
\hline & $(31.84)$ & $(-16.03)$ & (31.99) & (31.68) \\
\hline Observations & 4,397 & 4,397 & 4,397 & 4,397 \\
\hline R-squared & 0.443 & 0.297 & 0.444 & 0.445 \\
\hline
\end{tabular}

Table 5. JP_FOR Regression results

\begin{tabular}{lcccc}
\hline & $(1)$ & $(2)$ & $(3)$ & $(4)$ \\
VARIABLES & TobinQ & SCSR & TobinQ & TobinQ \\
\hline \multirow{2}{*}{ JP_FOR } & & & & \\
& $0.405^{*}$ & $8.624 * * *$ & & $0.355^{*}$ \\
SCSR & $(1.927)$ & $(3.661)$ & & $(1.671)$ \\
& & & $0.00603 * * *$ & $0.00584 * * *$ \\
SIZE & & & $(4.227)$ & $(4.072)$ \\
& $-0.337 * * *$ & $3.233^{* * *}$ & $-0.355^{* * * *}$ & $-0.356 * * *$ \\
ROA & $(-25.61)$ & $(25.70)$ & $(-24.98)$ & $(-25.07)$ \\
& $5.836 * * *$ & 3.036 & $5.811^{* * *}$ & $5.818^{* * *}$ \\
LEV & $(12.88)$ & $(1.150)$ & $(12.82)$ & $(12.85)$ \\
& $-0.448^{* * *}$ & $-5.888^{* * *}$ & $-0.411^{* * *}$ & $-0.414 * * *$ \\
GROW & $(-3.857)$ & $(-6.843)$ & $(-3.510)$ & $(-3.534)$ \\
& -0.0601 & -0.0325 & -0.0583 & -0.0599
\end{tabular}




\begin{tabular}{lcccc} 
& $(-1.066)$ & $(-0.0680)$ & $(-1.033)$ & $(-1.061)$ \\
STATE & $0.204 * * *$ & -0.285 & $0.203 * * *$ & $0.206^{* * *}$ \\
AGE & $(6.336)$ & $(-1.034)$ & $(6.323)$ & $(6.390)$ \\
LEAD & -0.00233 & -0.0343 & -0.00225 & -0.00213 \\
& $(-0.826)$ & $(-1.133)$ & $(-0.803)$ & $(-0.759)$ \\
Constant & 0.0319 & -0.278 & 0.0836 & 0.0336 \\
& $(0.509)$ & $(-0.494)$ & $(1.426)$ & $(0.534)$ \\
& $9.095 * * *$ & $-44.30 * * *$ & $9.327 * * *$ & $9.354 * * *$ \\
Observations & $(32.30)$ & $(-16.49)$ & $(31.99)$ & $(32.08)$ \\
R-squared & 4,397 & 4,397 & & 4,397 \\
\hline
\end{tabular}

\subsection{Returnees and Strategic Corporate Social Responsibility Orientation: Test of Hypothesis 1}

Column (2) in table 3, 4, and 5 show the OLS regression results of returnee executives on strategic CSR orientation, and each model is significant to the whole research. The first row of column (2) in table 3 shows that the orientation of strategic corporate social responsibility is significantly positively correlated with the proportion of overseas returnee executives in the executive team (P_FOR) at the $1 \%$ level, indicating that overseas returnee executives significantly promote the orientation of strategic social responsibility in enterprises. The first row of column (2) in table 4 shows a significant positive correlation between strategic CSR orientation and PROP_FOR at the $1 \%$ level, indicating that overseas returnees whose major background is economics or management can significantly promote strategic CSR orientation. The higher the proportion of overseas executives with such professional background in the senior management team, the better the promotion effect of strategic social responsibility orientation can be. The first row of column (2) in table 5 shows a significant positive correlation between strategic CSR orientation and JP_FOR at the $1 \%$ level. This shows that executives with overseas work experience significantly promote the orientation of corporate strategic social responsibility. The higher the proportion of overseas returnees with work experience in the senior management team, the better the effect of improving the orientation of corporate strategic social responsibility. The above results show that senior executives of overseas returnees significantly promote the orientation of corporate strategic social responsibility. Hypothesis 1 is supported by the above empirical evidence.

The control variables show a high degree of consistency in the (2) columns of tables 3, 4, and 5. There is a significant positive correlation between enterprise SIZE (SIZE) and corporate social responsibility strategic orientation (SCSR), indicating that the larger an enterprise is, the stronger its ability and strength may be. The more social responsibility related to its strategy can be found, the more likely it is to fulfill social responsibility. The asset-liability ratio (LEV) is significantly negatively correlated with corporate social responsibility strategic orientation (SCSR), indicating that the liability status is an important factor restricting the performance of corporate social responsibility. The more serious the liability status is, the less likely it is to perform social responsibility. ROA is positively correlated with corporate social responsibility strategic orientation (SCSR), but not significantly, indicating that ROA has a slight positive impact on corporate social responsibility strategic orientation (SCSR) in this sample. Enterprise growth (GROW) is negatively correlated with corporate social responsibility strategic orientation (SCSR), but it is not significant, indicating that the future development prospect of enterprises in this sample has a slight negative impact on corporate social responsibility strategy. There is no significant negative correlation between the nature of enterprise property rights (STATE) and the strategic orientation of enterprise social responsibility (SCSR), indicating that the incomplete market economy of enterprises with state-owned property rights will have a certain impact on their own social responsibility strategy. There is no significant negative correlation between company AGE and corporate social responsibility strategic orientation (SCSR), indicating that the longer the company's AGE is, the more difficult it is for the company's management inertia to integrate into strategic corporate social responsibility. The dummy variable of a corporate leader (LEAD) is not significantly negatively correlated with the strategic orientation of corporate social responsibility (SCSR), probably because the corporate social responsibility strategy is not only made by the corporate leader but depends on the group decision of the corporate senior management team.

\subsection{Returnee Executives and Enterprise Value: Testing of Hypothesis 2}

The first row of columns (1) and (4) in table 3, 4 and 5 respectively report the OLS regression results of returned executives and enterprise value (TobinQ), and each model is significant on the whole. The results of the first row (1) 
and (4) of table 3 show that the company value is significantly positively correlated with P_FOR at the 5\% level, indicating that senior executives of overseas returnees have significantly promoted the company value. The results of the first column (1) and (4) of table 4 respectively show that the company value and PROP_FOR are significantly positively correlated at the level of 5\% and $10 \%$ respectively, indicating that the advanced management level and strategic concept formed by the overseas returnee senior executives through their learning experience in the economic or management background promote the improvement of enterprise value. The results of the (1) and (4) columns of the first row in table 5 show that the company value is significantly positively correlated with JP_FOR at the $10 \%$ level, indicating that the work experience and management experience formed by overseas working or working experience can significantly promote the improvement of enterprise value. The joint results of column (1) - (3) show that senior executives of overseas returnees significantly promote the improvement of company value, and hypothesis 2 is supported by empirical evidence.

The control variables show a high degree of consistency in the columns (1) and (4) of table 3, 4 and 5.LEV is negatively correlated with the enterprise value (TobinQ), indicating that enterprises' high debt seriously restricts the growth of enterprise value. The nature of rights of property of enterprises (STATE) is significantly positively correlated with the enterprise value (TobinQ), indicating that state-owned enterprises are prone to gaining competitive advantages due to the inclination of national policies and resources in an incomplete market environment, thus increasing enterprise value. ROA is significantly positively correlated with TobinQ, indicating that the market has a positive response to profitability. The higher the profitability, the higher the market pricing. Enterprise growth (GROW) is negatively correlated with enterprise value (TobinQ), but it is not significant, indicating that the better the enterprise growth is, the more likely it is to consume the resources and value of the enterprise. Due to the lag of enterprise value return, the consumption of enterprise resources and value is often more than the new enterprise value obtained, resulting in the reduction of enterprise value. There is no significant negative correlation between company AGE and the enterprise value (TobinQ), indicating that the longer the company's AGE is, after the period of rapid growth, the more difficult it is to continue to maintain the rapid growth of enterprise value, and it may slowly enter the period of decline of enterprise value. The dummy variable of enterprise leader (LEAD) is positively correlated with the enterprise value (TobinQ), but it is not significant, which indicates that as leaders of enterprises, the returnees' human capital advantages such as the concept of corporate social responsibility and strategic decision-making consciousness will promote the growth of enterprise value to some extent.

\subsection{Intermediary Effect Test of Returnee Executives Affecting Enterprise Value Through Strategic Corporate Social Responsibility Orientation}

The (1) - (4) columns in tables 3, 4, and 5 show the results of the recursive model test and the overall significance of each model. From columns (1) and (4), it can be found that enterprise value (TobinQ) is significantly positively correlated with various indicators of returnee senior executives at above $10 \%$ level. From columns (3) and (4), it can be found that strategic corporate social responsibility orientation (SCSR) and enterprise value (TobinQ) are significantly positively correlated at the $1 \%$ level. From the comprehensive (2) column, it can be found that strategic corporate social responsibility orientation (SCSR) is significantly positively correlated with various indicators of overseas returnees at the $1 \%$ level. Column (4) shows the regression results of various variables including strategic corporate social responsibility orientation (SCSR) and overseas returnees. The results show that enterprise value (TobinQ) is significantly positively correlated with strategic corporate social responsibility orientation (SCSR) at the level of $1 \%$ and positively correlated with various indicators of overseas returnees at the level of 5\% or $10 \%$. It shows that at least part of the relationship between overseas returnee executives and corporate value is generated through the "strategic corporate social responsibility orientation", that is, there is a mediating effect. Hypothesis 3 is supported by empirical evidence.

\subsection{Robustness Test}

According to the different methods of enterprise value evaluation, different viewpoints and methods have been formed on the measurement and evaluation of enterprise value. In order to make the results of this paper robust, this paper considers using other enterprise value indicators to replace Tobin's $Q$ value for regression, as an assessment tool to evaluate the ability of managers to improve enterprise value. In this paper, Eva is considered to be a good indicator of enterprise value substitution, and it is considered to use Eva to replace Tobin's Q value for regression. In this paper, the value added to the economy is divided by the ratio of average assets to represent the level of the value added to the economy. Since the average value of this index is less than 1, this paper multiplies this variable by 100 (if the processing is not done, the coefficient of the independent variable will be too small). That is, eva = EVA / average total assets. Where EVA is calculated as:

Economic value-added EVA $=$ Net operating profit after tax $($ NOPAT $)$-total capital $*$ weighted average cost of capital (WACC). 
The EVA data used in this article is from the EVA special research database of CSMAR Chinese listed companies.

The coefficients and symbols of the explanatory variables in the robustness test results table are consistent with the above conclusions, indicating that the above conclusions are robust, the three assumptions are still valid, and the mediating effect exists. According to the analysis above, all the results show that returnee executives will indeed have an impact on corporate value through the intermediary channels of strategic corporate social responsibility.

\subsection{Conclusion}

With empirical analysis, all hypotheses of this paper have been verified:

1) A positive and significant impact of returnee executives on strategic corporate social responsibility orientation;

2) The positive and significant promotion effect of returnee executives on corporate value;

3) Significantly positive intermediary effect of strategic corporate social responsibility orientation between returnee executives and corporate value.

\section{Discussion}

This article explores the impact of overseas work or study experience of returnee executives on corporate value and its operating mechanism. The study finds that the overseas background of executives plays an important role in the promotion of corporate value, but the impact is not direct. Instead, the strategic corporate social responsibility orientation is used as an intermediary, that is, returnee executives are positively affecting the value of an enterprise by improving the social responsibility orientation in corporate strategy.

The theoretical contribution of this paper is to start from strategic corporate social responsibility and provide a new perspective for the study of the role of returnee executives in the promotion of enterprise value at the micro-enterprise level. In the past, most scholars have discussed the role of returnees from the perspectives of overseas financing, overseas mergers and acquisitions, overseas investment, and technological innovation. However, rarely have they studied the impact of returnees on corporate value from the perspective of strategic corporate social responsibility. This paper to some extent fills the gaps in relevant theoretical research. This research has considerable significance in management practice: (1) companies can start with the governance structure and build an appropriate senior management team to improve corporate social responsibility performance and corporate value; (2) This paper provides empirical evidence for evaluating the effect of China's overseas high-level talent introduction policy.

\section{References}

Chen, T. (2010). The Cultivation of Social Responsibility of Strategic Enterprises. Commercial Times, 23, 87-88.

Du, X. Q., Zeng, Q., \& Du, Y. J. (2011). Political Connection, Excessive Investment and Company Value: Based on The Empirical Evidence of State-Owned Listed Companies. Journal of Financial Research, 374(8), 93-110.

Fei, S. K., \& Yu, P. K. (2010). Research on The Supervisory Role of Foreign Executives in Chinese Listed Enterprises. Nankai Management Review, 13(2), 16-22.

Ge, Y. H., \& Shen, S. M. (2011). International role of executive team in global strategic decision-making: foreign market entry model. Contemporary economic management, 33(09), 53-58.

He, Y. N., \& Zhang, X. D. (2018). Overseas returnees' executives, political relations and earnings management. Financial and economic theory \& practice, 39(1), 76-83.

Jia, Y. J. (2006). Value Identification in The Process of Economic Globalization. Academic Seminar on Value Theory and Methods. 2006.

Li, D. W., \& Wu, J. (2017). Influence of Heterogeneity of Executive Team on Corporate Social Performance. Management Review, 29(12), 86-95.

Li, Z.J., Li, Y., \& Chen, D. (2010) Internationalization Experience and Globalization -- An Empirical Study Based on Listed Companies In China's Electronic Information Technology Industry. China Soft Science, 8, 126-137.

Liu, J. H. (2013). Research on the Lack of Corporate Social Responsibility and Its Promotion Path in China. Journal of Jinan University (Social Science Edition), 23(1), 92-96.

Lu, D. F. (2001). Comment on the Social Reliability of the Foreign Enterprises. Modern Law Science, 3, 137-144.

Lu, W. C. (2017). A Cross-Cultural Comparative Study of Corporate Social Responsibility In China And The West. Henan Social Sciences, 11, 82-87.

Ren, F., \& Guo, X. R. (2017). Analysis of New Ways to Overcome the Disadvantages of Outsiders: The Role of Strategic Social Responsibility. Modern Management Science, 2, 40-42. 
Rosen S. (2008). Human Capital. In: Palgrave Macmillan (eds) The New Palgrave Dictionary of Economics. Palgrave Macmillan, London. https://doi.org/10.1057/978-1-349-95121-5_743-2

Shao, X. D., \& Meng, X. Z. (2015). Strategic Corporate Social Responsibility in the Transitional Period. Research on Economics and Management, 36(09), 121-129.

Song, Q. Q. (2015). Corporate Social Responsibility, Stakeholder Response and Corporate Value. China Township Enterprises Accounting, 7, 173-174.

Wang, S. Y., \& Gao, X. D. (2008). Which human capital is more effective for overseas returnee entrepreneurs: management or technology? Scientific research management, 39(02), 1-9.

Wen, W., \& Song, J. B. (2017) Executive overseas background and corporate social responsibility. Management science, 30(02), 119-131.

Wen, Z. L., Zhang, L., Hou, J. T., \& Liu, H. Y. (2004). Testing and Application of The Mediating Effects. Acta Psychologica Sinica, 05, 614-620.

Xia, X. C. (2010). An Empirical research of Strategic CSR impact on brand equity. Tianjin University.

Xu, J. Y., \& Sun W. N. (2017) Does overseas study experience promote the export of enterprises. International trade issues, 10, 37-48.

Xu, X. X., Zhu, H. Y., Gan, W. Y., \& Li, W. L. (2018). Returnee Executives and Improvement of Corporate Social Responsibility Performance: An Empirical Study Based on Cultural Convergence. Foreign Economics \& Management, 40(05), 99-112.

Yi, K. G. (2012). Corporate Social Responsibility Education for Business Talents: Concept, Dilemma and Countermeasures. Education Research, 2012(1), 152-157.

Zhang, J. J., \& Li, H. W. (2017). Entrepreneur background, diversification strategy and corporate performance in private enterprises. Nankai Management Review, 5, 12-25.

Zhang, X. D., \& Wu, J. (2016). Can overseas executives promote technological innovation? [J]. Science of science and management of science and technology, 37(01), 115-128.

Zhou, W. (2014). Research on corporate executive education background and risk tolerance level. Wuhan University, 2014.

\section{Copyrights}

Copyright for this article is retained by the author(s), with first publication rights granted to the journal.

This is an open-access article distributed under the terms and conditions of the Creative Commons Attribution license which permits unrestricted use, distribution, and reproduction in any medium, provided the original work is properly cited. 